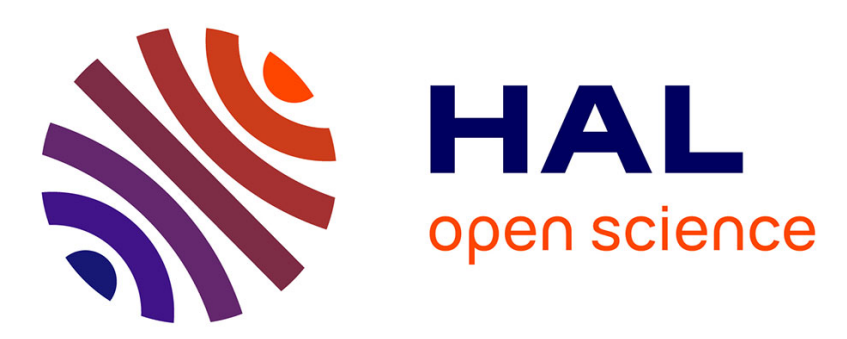

\title{
A new method for the determination of 2-acetolactate in dairy products
}

\author{
B. Mohr, F. Aymes, M.C. Rea, Christophe C. Monnet, T.M. Cogan
}

\section{To cite this version:}

B. Mohr, F. Aymes, M.C. Rea, Christophe C. Monnet, T.M. Cogan. A new method for the determination of 2-acetolactate in dairy products. International Dairy Journal, 1997, 7, pp.701-706. hal-02693358

\section{HAL Id: hal-02693358 \\ https: / hal.inrae.fr/hal-02693358}

Submitted on 1 Jun 2020

HAL is a multi-disciplinary open access archive for the deposit and dissemination of scientific research documents, whether they are published or not. The documents may come from teaching and research institutions in France or abroad, or from public or private research centers.
L'archive ouverte pluridisciplinaire HAL, est destinée au dépôt et à la diffusion de documents scientifiques de niveau recherche, publiés ou non, émanant des établissements d'enseignement et de recherche français ou étrangers, des laboratoires publics ou privés. 
1 A New Method for the Determination of 2-Acetolactate in Dairy Products

3

${ }^{1}$ National Dairy Products Research Centre, Moorepark, Fermoy, Co.Cork, Ireland.

${ }^{2}$ Institut National de la Recherche Agronomique, Laboratoire de Génie et Microbiologie des Procédés Alimentaires, 78850 Thiverval-Grignon, France

Britta Mohr ${ }^{1}$, Frédéric Aymes ${ }^{2}$, Mary C. Rea ${ }^{1}$, Christophe Monnet $^{2}$ and Timothy M. Cogan'.

\section{ABSTRACT}

Haemin, $\mathrm{Fe}^{3+}$ and $\mathrm{Cu}^{2+}$ caused significant decarboxylation of 2-acetolactate (ALA) to diacetyl during steam distillation of milk at $\mathrm{pH}$ 6.5. In the absence of these compounds, maximum conversion (28\%) of ALA to diacetyl occurred at $\mathrm{pH} 3.5$. Addition of $1.5 \mathrm{mM} \mathrm{CuSO}_{4}$ at this $\mathrm{pH}$ increased the conversion to $100 \%$. Based on this result, a new method for the determination of ALA was developed, in which interference from pre-formed acetoin was minimised. Comparison of this method with the previous method (Jordan and Cogan, 1995) with which high concentrations of acetoin interfere, was excellent $\left(\mathrm{R}^{2}=0.96\right)$. Breakdown of ALA to diacetyl in the absence of $\mathrm{Cu}$ at $\mathrm{pH} 0.5$ and 6.5 were 0.8 and $2.5 \%$ respectively, implying that samples for diacetyl analysis should be adjusted to $\mathrm{pH} 0.5$ before distillation if ALA is also suspected to be present. In quarg $(\mathrm{pH} 4.5)$ held at $4{ }^{\circ} \mathrm{C}$, ALA was degraded at a rate of 6.9-16.9 $\mu$ moles/L/day and from 32-50\% of the degraded ALA was converted to diacetyl during extended storage. 
2 Citrate utilising $\left(\mathrm{Cit}^{+}\right)$Lactococcus lactis subsp. lactis produce diacetyl, acetoin and 2-

3 acetolactate (ALA) from citrate in milk fermentations. Diacetyl, although produced in the smallest amounts, is the most important of these compounds as it is responsible for flavour in many fermented dairy products including lactic butter, quarg or buttermilk. ALA is extremely unstable and is easily decarboxylated either oxidatively to diacetyl or non-oxidatively to acetoin (de Man and Pette, 1956). Whether decarboxylation to diacetyl during fermentations occurs enzymatically or chemically is still not clear. Until recently the evidence was in favour of chemical formation but the results of Jordan et al. (1996) provide strong evidence for enzymatic production too. Normally little ALA accumulates in cultures because of the activity of 2-acetolactate decarboxylase (ALD), which is responsible for the production of acetoin from ALA. ALD negative mutants can be selected relatively easily and accumulate ALA which can be converted chemically to diacetyl (Monnet et al., 1997). A naturally occurring ALD negative strain of Lc. lactis subsp. lactis is used in the NIZO process for lactic butter manufacture and the accumulated ALA is converted chemically to diacetyl by aeration at low $\mathrm{pH}$.

A problem arises when the three compounds, ALA, acetoin and diacetyl must be measured in the same sample. ALA is normally measured as acetoin after decarboxylation by heat (Veringa et al. 1984) or acid (Jordan and Cogan, 1988; 1995). After treatment, the samples are assayed for acetoin using the Westerfeld method (1945) and ALA is calculated as the difference in the level of acetoin between the treated and untreated samples. This procedure results in inaccurate measurement of ALA if the level of acetoin in the sample is high compared to that of ALA. Diacetyl is also measured by the Westerfeld procedure but it normally does not interfere with the 
measurement of acetoin since much smaller amounts of diacetyl are produced than acetoin. Methods for the measurement of diacetyl with which acetoin does not interfere are available e.g. that of Prill and Hammer (1938). Such methods often involve a steam distillation step to separate the diacetyl from the sample (Walsh and Cogan, 1974). When samples which contain ALA are heat-treated, the ALA present in the sample is converted to diacetyl and acetoin which leads to overestimation of both compounds (Veringa et al., 1984). Veringa et al. (1984) and Cronin and Rispin (1996) reported that breakdown of ALA to diacetyl during distillation can be reduced to 2 or $0.2 \%$ by adjusting the $\mathrm{pH}$ of the samples prior to distillation to 9.0 or 1.0 respectively. Gollop et al. (1987) developed a method to measure ALA which involved the oxidative decarboxylation of ALA to diacetyl at $80^{\circ} \mathrm{C}$ in the presence of $\mathrm{Fe}^{2+}$ and $\mathrm{Fe}^{3+}$. The objectives of the present study were to modify the method of Gollop et al (1987) for estimating ALA in dairy products. Preformed acetoin would not interfere with such a method.

\section{MATERIALS AND METHODS}

\section{Breakdown of synthetic 2-acetolactate}

ALA was obtained by saponification of 2-acetoxy-2-methylacetoacetate (Aldrich Chemical Company, P.O. Box 355, Milwaukee, Wisconsin. 53201 USA) with two equivalents of $\mathrm{NaOH}$ for $15 \mathrm{~min}$ before use. $\mathrm{CuSO}_{4}, \mathrm{FeCl}_{3}$ and haemin (Sigma Chemical Company, Poole, Dorset BH17 7NH, England) were added to reconstituted heat-treated $\left(121^{\circ} \mathrm{C}\right.$ for $\left.5 \mathrm{~min}\right)$ skim milk (RSM) $(100 \mathrm{~g} / \mathrm{l}), \mathrm{pH} 6.5$, containing the required amount of ALA. Samples were analysed for ALA and acetoin by the Jordan and Cogan (1995) modification of the Westerfeld (1945) method, and for diacetyl in 
the first 10ml of steam distillate by the Walsh and Cogan (1974) modification of the Prill and Hammer (1938) method. The Jordan and Cogan (1995) method for measuring ALA and acetoin does not involve distillation; instead ALA is decarboxylated to acetoin by $\mathrm{HCl}$ at $4{ }^{\circ} \mathrm{C}$ and the ALA concentration is obtained by subtracting the level of acetoin obtained in the absence of $\mathrm{HCl}$ from that obtained in its presence. Occasionally acetoin was also measured in the $2 \mathrm{nd} 10 \mathrm{ml}$ of steam distillate by the Westerfeld (1945) procedure.

\section{Final method for estimating ALA}

To $3 \mathrm{ml}$ of sample, $5.5 \mathrm{ml}$ of buffer $\left[0.2 \mathrm{M}\right.$ citric acid and $0.4 \mathrm{M} \mathrm{Na}_{2} \mathrm{HPO}_{4}$, mixed in a ratio of 2.56:1] and $1.5 \mathrm{ml}$ of $10 \mathrm{mM} \mathrm{CuSO}_{4}$ in the buffer was added. For samples with low diacetyl concentrations, the amount of sample was increased to $9 \mathrm{ml}$ and the amount of $\mathrm{CuSO}_{4}$ buffer solution to $21 \mathrm{ml}$. The final $\mathrm{Cu}^{2+}$ concentration was $1.5 \mathrm{mM}$ and the $\mathrm{pH}$ of the mixture of sample, buffer and $\mathrm{CuSO}_{4}$ was 3.5. The mixture was steam distilled and the first $10 \mathrm{ml}$ of distillate collected for diacetyl determination. Samples were also distilled using water instead of the $\mathrm{CuSO}_{4}$ buffer solution and adjusting the $\mathrm{pH}$ to 0.5 using $5 \mathrm{M} \mathrm{H}_{2} \mathrm{SO}_{4}$. The addition of $700 \mu \mathrm{l}$ of $5 \mathrm{M} \mathrm{H}_{2} \mathrm{SO}_{4}$ to $10 \mathrm{ml}$ of milk or lactic culture reduced the $\mathrm{pH}$ from 6.5 and 4.5 respectively to 0.5 . The ALA concentration of the sample was calculated as the difference in diacetyl concentrations between the sample distilled at $\mathrm{pH} 3.5$ in the presence of $\mathrm{CuSO}_{4}$ and the sample distilled at $\mathrm{pH} 0.5$ in the absence of $\mathrm{CuSO}_{4}$.

\section{Comparison of Westerfeld and $\mathrm{CuSO}_{4}$ method for ALA determination}

Lc. lactis subsp. lactis strains 4/25A and 1166M1 and Lactobacillus casei 4191M3 were used. Strain $4 / 25 \mathrm{~A}$ is a naturally occurring ALD negative mutant while the others 
were selected by mutation of their respective parents (Monnet et al. 1997). Strains 1166 and 4/25A were from the DPC collection (Moorepark, Fermoy, Co. Cork, Ireland); while 4191 was from the Centre de Recherche International 'André Gaillard', Yoplait (Ivry sur Seine, France). Heat treated RSM was inoculated with 10g/l of a fresh culture and incubated at $30^{\circ} \mathrm{C}$ under static conditions. The cultures were sampled at regular intervals and ALA was determined using both the Westerfeld (1945) method modified by Jordan and Cogan (1995) and the $\mathrm{CuSO}_{4}$ method.

\section{Quarg}

Quarg samples containing different levels of ALA were obtained from the Centre de Recherche International 'André Gaillard', Yoplait (Ivry sur Seine, France). Triplicate samples were analysed for ALA, using the $\mathrm{CuSO}_{4}$ method, and diacetyl during storage at $4^{\circ} \mathrm{C}$.

\section{RESULTS.}

In the Westerfeld procedure, ALA is usually determined as the difference in the acetoin concentrations before and after decarboxylation by heat (Veringa et al. 1984) or acid (Jordan and Cogan, 1988; 1995). Where two compounds are measured by the same procedure, like ALA and acetoin, the CV of ALA is related to the CV acetoin by the following equation (Dagnélie, 1973):

$$
\mathrm{CV}_{\mathrm{ALA}}=\mathrm{CV}_{\mathrm{ACETOIN}} \sqrt{1+2(r+1) / r 2}
$$

where $\mathrm{CV}_{\mathrm{ALA}}$ and $\mathrm{CV}_{\mathrm{ACETOIN}}$ are the coefficients of variation of ALA and acetoin respectively and $r$ is the ratio of the concentration of ALA to that of acetoin. This equation can be used to construct a series of lines, relating the $\mathrm{CV}_{\mathrm{ALA}}$ to the ratio of 


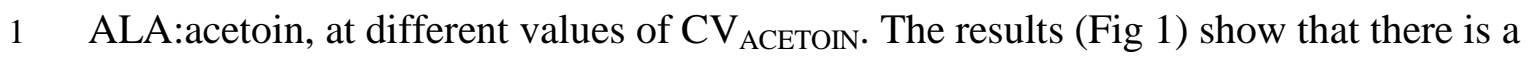

2 significant increase in the $\mathrm{CV}_{\mathrm{ALA}}$ when the ALA:acetoin ratio is low, which is

3 normally the case in LAB. Under these circumstances, the measurement of ALA is

4 inaccurate. It is generally regarded that the $\mathrm{CV}$ for acetoin is $\sim 5 \%$. At this value and

5 at an ALA:acetoin ratio of 0.4 , the $\mathrm{CV}_{\mathrm{ALA}}$ is $21.5 \%$. Many $\mathrm{LAB}$, especially citrate

6 utilizing Lc. lactis subsp. lactis, produce small amounts $(<0.1 \mathrm{mM})$ of diacetyl and

7 large amounts of acetoin (up to $4 \mathrm{mM}$ ) in milk, so that a method for measuring ALA

8 based on diacetyl rather than acetoin would be particularly useful. In this case the

9 ALA:diacetyl ratio would be high and estimates of ALA would be accurate.

10 Gollop et al. (1987) proposed a method for the determination of ALA, in

which ALA is oxidatively decarboxylated to diacetyl by heating at $80^{\circ} \mathrm{C}$ for $10 \mathrm{~min}$ at $\mathrm{pH} 4.0$ in the presence of $0.15 \mathrm{mM}$ each of $\mathrm{FeCl}_{3}$ and $\mathrm{FeSO}_{4}$ followed by 'air' distillation at $60^{\circ} \mathrm{C}$. When this method was evaluated in samples which were steam distilled at $100^{\circ} \mathrm{C}$ rather than 'air' distilled at $60^{\circ} \mathrm{C}$, the conversion of ALA to diacetyl was low and not directly proportional to the concentration of ALA in the sample (Fig. 2). It was, therefore, considered to be unsatisfactory.

The effect of $\mathrm{pH}$ on the conversion of ALA to diacetyl is shown in Fig.3. Maximum conversion (28\%) occurred at $\mathrm{pH} 3.5$ and $0.8 \%$ was converted at $\mathrm{pH} 0.5$. At $\mathrm{pH} 6.5$, the normal $\mathrm{pH}$ of milk, $\sim 2.5 \%$ would be converted. The findings at $\mathrm{pH} 0.5$ agree with those of Cronin and Rispin (1996).

Various concentrations of $\mathrm{Cu}^{2+}, \mathrm{Fe}^{3+}$ and haemin were investigated for their ability to transform ALA to diacetyl during steam distillation. The results (Table 1) show that more diacetyl was formed in the presence of $\mathrm{Cu}^{2+}$ than $\mathrm{Fe}^{3+}$ and significant production also occurred in the presence of haemin. These experiments were carried out in milk at $\mathrm{pH} 6.5$ but the results would probably show the same relativities, if the 
milk had been adjusted to $\mathrm{pH} 3.5$ prior to distillation, except that conversion to diacetyl would be greater. To find the optimum concentration of $\mathrm{CuSO}_{4}$ necessary for transformation of ALA, 1mM ALA in RSM was distilled in the presence of a range of $\mathrm{CuSO}_{4}$ solutions made up in $18.8 \mathrm{mM} \mathrm{H}_{2} \mathrm{SO}_{4}$. The $\mathrm{pH}$ of the mixture of $\mathrm{CuSO}_{4}$ solution and RSM was 3.5. The results (Fig. 4) showed that conversion to diacetyl increased as the $\mathrm{CuSO}_{4}$ concentration increased and that recovery was $98 \%$ in the presence of $1.5 \mathrm{mM} \mathrm{CuSO}_{4}$.

To measure ALA accurately, it is important to determine the conditions where the breakdown of ALA to diacetyl is minimised, which will give the true diacetyl concentration in the sample, and maximised, which will give the total of ALA plus diacetyl. The actual level of ALA is obtained by difference. Standard curves containing $0.25-4 \mathrm{mmol} \mathrm{ALA} / \mathrm{l}$ were distilled at $\mathrm{pH} 3.5$, in the presence of $1.5 \mathrm{mmol}$ $\mathrm{CuSO}_{4} / \mathrm{l}$ (in $18.8 \mathrm{mmol} \mathrm{H}_{2} \mathrm{SO}_{4} / \mathrm{l}$ ) and, at $\mathrm{pH} 0.5$, in the absence of copper, and the levels of diacetyl and acetoin determined in the 1st and 2nd $10 \mathrm{ml}$ fractions of distillate. The results (Fig 5) show that, ALA was transformed to $102 \%$ diacetyl and little or no acetoin at $\mathrm{pH} 3.5$, in the presence of $\mathrm{Cu}^{2+}$, and to $93 \%$ of acetoin and little or no diacetyl at $\mathrm{pH} 0.5$ in the absence of $\mathrm{Cu}^{2+}$. Production of diacetyl at $\mathrm{pH} 0.5$ was $1.3 \%$. These results imply that diacetyl should be determined at $\mathrm{pH} 0.5$ in the absence of $\mathrm{Cu}^{2+}$ and ALA at $\mathrm{pH} 3.5$ in the presence of $\mathrm{Cu}^{2+}$. The figures for ALA should then be corrected for any 'free' diacetyl to obtain the true level of ALA in the sample. The $100 \%$ recovery of diacetyl from ALA in the presence of $\mathrm{Cu}^{2+}$ was confirmed by running 10 standard curves and estimating the s.d. about each point (Fig. 5). The s.ds. were small indicating that the method is very reproducible. At ALA concentrations $>4 \mathrm{mM}$, breakdown rates at $\mathrm{pH} 3.5$ decreased due to incomplete 
recovery of the large amounts of diacetyl in the first $10 \mathrm{ml}$ of steam distillate, which is the fraction used for the determination of diacetyl.

At $\mathrm{pH} 3.5$, standard curves for acetoin $(0.25$ to $4 \mathrm{mM})$ in RSM in the presence and absence of $\mathrm{CuSO}_{4}$ were superimposable, indicating that $\mathrm{Cu}^{2+}$ did not catalyse the conversion of acetoin to diacetyl (data not shown). This result implies that acetoin does not interfere with the measurement of ALA by the $\mathrm{CuSO}_{4}$ method.

$\mathrm{Cu}_{2} \mathrm{SO}_{4} / \mathrm{H}_{2} \mathrm{SO}_{4}$ is a strong acid and significant variation in $\mathrm{pH}$ in mixtures of it and sample could result, depending on the buffer capacity of the sample. Changing the $\mathrm{pH}$ by \pm 0.5 of a $\mathrm{pH}$ unit from $\mathrm{pH} 3.5$ in the presence of $1.5 \mathrm{mM} \mathrm{CuSO}_{4}$ resulted in only $80 \%$ recovery of the ALA as diacetyl, whereas a change of \pm 0.3 of a pH unit resulted in $100 \%$ recovery as diacetyl. These results imply that the $\mathrm{pH}$ of the mixture must be carefully controlled. Use of a buffer [0.2 $\mathrm{M}$ citric acid and $0.4 \mathrm{M} \mathrm{Na}_{2} \mathrm{HPO}_{4}$ mixed in a ratio of 2.56:1] instead of $\mathrm{H}_{2} \mathrm{SO}_{4}$ also showed $100 \%$ recovery of ALA as diacetyl in the standard curves. The buffer $\mathrm{pH}$ was 3.3 and resulted in a $\mathrm{pH}$ of 3.5 when RSM was mixed with it and the $\mathrm{CuSO}_{4}$ solution. During growth, acid production by Lc. lactis subsp. lactis can decrease the $\mathrm{pH}$ of milk from 6.5 to 4.5 . Samples taken at various stages during growth in milk when mixed with the $\mathrm{CuSO}_{4} /$ buffer resulted in a pH of $3.5 \pm 0.05$ indicating that the buffer retained the correct $\mathrm{pH}$ over the range of $\mathrm{pH}$ values expected in a typical milk fermentation. The Westerfeld (1945) method as modified by Jordan and Cogan (1995) is commonly used to measure ALA. To determine how this method compared with the new method three ALD negative mutants, Lc. lactis subsp. lactis 4/25A and 1166M1 and $\mathrm{Lb}$. casei $4191 \mathrm{M} 3$ were grown in $\mathrm{RSM}$ at $30^{\circ} \mathrm{C}$ and sampled at intervals for ALA using both methods. Figure 6 shows that the correlation between the two methods is very good and indicates that the $\mathrm{CuSO}_{4}$ method overestimates ALA by $5.7 \%$ 
compared with the Westerfeld method. This is probably due to the inherent inaccuracy in the Westerfeld method when the ALA concentration is low compared to that of acetoin (Fig 1).

As a further test of the applicability of the method, four samples of quarg $(\mathrm{pH}$ 4.5) were analysed for diacetyl and ALA, using the $\mathrm{CuSO}_{4}$ method, during storage at $4^{\circ} \mathrm{C}$. The differences between replicate samples was $<6 \%$ for both compounds. For practical reasons it was not possible to measure the levels at day 0 nor ALA by the Westerfeld (1945) procedure as the acetoin concentration was $3 \mathrm{mM}$ and the ALA:acetoin ratio was too low to give reliable results (Fig. 1). An inverse relationship was observed between the disappearance of ALA and appearance of diacetyl during storage (Fig. 7). The rates of ALA degradation in samples A, B, C and D were 6.9, 14.6, 11.5 and $16.9 \mu$ moles/ L/day respectively. Regression of the three diacetyl values on the three ALA values in each sample gave $\mathrm{R}^{2}$ values of $>0.98$ and conversion rates of $44,37,50$ and $32 \%$ for samples A, B, C and D respectively.

\section{DISCUSSION}

The results in this paper show that ALA can be effectively measured as diacetyl after distillation in the presence of $\mathrm{Cu}^{2+}$ at $\mathrm{pH}$ 3.5. Diacetyl itself should be measured in samples adjusted to $\mathrm{pH} 0.5$ and the ALA concentrations corrected accordingly. The mechanism of the $\mathrm{Cu}$ or Fe catalysed formation of diacetyl from ALA is not clear. Gollop et al (1987) thought that a complex between the enediol, formed after decarboxylation of the ALA, and a $\mathrm{Cu}^{2+}-\mathrm{O}_{2}$ complex was involved. ALA can also be measured as acetoin by the Westerfeld method (1945) before and after decarboxylation with $\mathrm{HCl}$ (Jordan and Cogan, 1995). The Westerfeld method does not measure ALA concentrations satisfactorily when the ALA concentration is low 
compared to acetoin, which is commonly the case in many LAB. In citrate utilising lactococci, diacetyl is normally produced in small concentrations $(<0.1 \mathrm{mM})$ compared to acetoin which is produced in large concentrations (up to $4 \mathrm{mM}$ ). In this case, low relative errors during the measurement of acetoin result in high relative errors in determining ALA because of the fact that ALA is calculated as a difference (Fig. 1). The relationship between the $\mathrm{CuSO}_{4}$ and Westerfeld methods for the determination of ALA was good but the $\mathrm{Cu}_{2} \mathrm{SO}_{4}$ method is considered to be the better method because small amounts of 'free' diacetyl will not influence the measurement of ALA as diacetyl to any great extent. In this case, the ratio of ALA:diacetyl would be high and would not affect the CV (Fig 1).

Kaneko et al. $(1987,1990)$ have reported, that growing $\mathrm{Cit}^{+}$Lactococcus lactis subsp. lactis in RSM in the presence of metal ions $\left(\mathrm{Cu}^{2+}, \mathrm{Fe}^{2+}, \mathrm{Fe}^{3+}\right.$, and $\left.\mathrm{Mo}^{6+}\right)$ or haemin increased the production of diacetyl during growth, with $\mathrm{Cu}^{2+}$ being the most effective. The results of our study show that if ALA is produced by a culture it can be converted to diacetyl at a high rate by heat in the presence of metal ions or haemin, haemin and $\mathrm{Cu}^{2+}$ being more effective than $\mathrm{Fe}^{2+}$. The results of Kaneko et al.(1987, 1990) could be due to an artefact of the method of analysis used by them (i.e. head space analysis after heating at $80^{\circ} \mathrm{C}$ for $30 \mathrm{~min}$ ) which resulted in oxidation of the ALA to diacetyl during analysis rather than a true effect of the metal ions or haemin on diacetyl synthase formation. Unfortunately, Kaneko et al. $(1987,1990)$ did not report whether their strain produced ALA.

In cultured dairy products such as lactic butter, buttermilk and quarg, 1-5 mg of diacetyl/L is required to give organoleptically acceptable products. It is important to be able to detect the levels of ALA in these products post-manufacture in order to determine the potential of the product to develop diacetyl during storage, particularly 
where ALD negative mutants, are used. Monnet et al. (1994) have shown that the rate of degradation of ALA decreases with decrease in temperature. However, the present results show that even when quarg was stored at $4^{\circ} \mathrm{C}$, a significant proportion (32$50 \%$ ) of the ALA is spontaneously decarboxylated to diacetyl during storage over extended periods.

ACKNOWLEDGMENTS This research was partially funded under Contract No. AIR3-CT94-2010 from the European Commission and by Irish Dairy Farmer Funds.

\section{REFERENCES}

Cronin, D.A. and Rispin, E. (1996) The determination of diacetyl in cultured buttermilk in the presence of the unstable precursor $\alpha$-acetolactic acid. $8^{\text {th }}$ Weurman Flavour Research Symposium, Reading UK, 22-26th July 1996.

Dagnélie, P. 1973 In: Théories et Methodés Statistiques. Vol 1, p186. Presses Agronomique de Gembloux, Gembloux Belgium.

De Man, J.C. and Pette, J.W. (1956) The mechanism of diacetyl formation in butter and starters. $14^{\text {th }}$ International Dairy Congress, Vol.2, Part 1, p 89.

Gollop, N., Barak, Z. and Chipman, D.M. (1987) A method for simultaneous determination of the two possible products of acetohydroxy acid synthase. Analytical Biochemistry, 160, 323-331.

Jordan, K.N. and Cogan, T.M. (1988) Production of acetolactate by Streptococcus diacetylactis and Leuconostoc sp. Journal of Dairy Research, 55, 227-238.

Jordan, K.N. and Cogan, T.M. (1995) Growth and metabolite production by mixedstrain starter cultures. Irish Journal of Agricultural and Food Research, 34, 39-47. 
Jordan, K.N., O'Donoghue, M., Condon, S. and Cogan, T.M. (1996) Formation of diacetyl by cell-free extracts of Leuconostoc lactis. FEMS Microbiology Letters 143, 291-297

Kaneko, T., Suzuki, H. and Takahashi, T. (1987) The effects of metal ions on diacetyl production by Streptococcus lactis subsp. diacetilactis 3022. Agricultural and Biological Chemistry, 51: 2315-2320.

Kaneko, T., Takahashi, T. and Suzuki, H. (1990) Acetoin fermentation by citrate positive Lactococcus lactis subsp. lactis 3022 grown aerobically in the presence of haemin or $\mathrm{Cu}^{+}$. Applied and Environmental Microbiology, 56, 2644-2649

Monnet, C., Schmitt, P. and Diviès, C. (1994) Diacetyl production in milk by an $\alpha-$ acetolactic acid accumulating strain of Lactococcus lactis ssp. lactis biovar diacetylactis. Journal of Dairy Science, 77, 29116-2924

Monnet, C., Schmitt, P. and Diviès, C. (1997) Development and use of a screening procedure for production of $\alpha$ - acetolactate by Lactococcus lactis subsp. lactis biovar diacetylactis strains. Applied and Environmental Microbiology, 63, 793795.

Prill, E.A. and Hammer, B.W. (1938) A colorimetric method for the microdetermination of diacetyl. Iowa State College Journal of Science, 12, 385-395.

Veringa, H.A., Verburg, E.H. and Stadhouders, J. (1984) Determination of diacetyl in dairy products containing $\alpha$-acetolactic acid. Netherlands Milk and Dairy Journal, 38, 251-263.

Walsh, B. and Cogan, T. M. (1974) Separation and estimation of acetoin and diacetyl in milk. Journal of Dairy Research, 41, 25-30 
1 Westerfeld, W.W. (1945) A colorimetric determination of blood acetoin. Journal of 2 Biological Chemistry, 161, 495-502 
1 Table 1. Decarboxylation of 2-acetolactate to diacetyl in RSM at pH 6.5 during

2 steam distillation $^{\mathrm{a}}$

\begin{tabular}{lllll}
\hline Additive & Concentration & $\mathrm{n}$ & Decarboxylatio & $\mathrm{sd}$ \\
& $\mathrm{mM}$ & \multicolumn{2}{l}{$\mathrm{n}$} \\
\hline Haemin & 0.01 & 5 & 9.3 & 1.8 \\
& 0.10 & 4 & 26.7 & 4.2 \\
$\mathrm{CuSO}_{4}$ & 0.10 & 1 & 21.1 & 3.9 \\
& 0.20 & 3 & 22.7 & \\
$\mathrm{FeCl}_{3}$ & 2.00 & 1 & 67.3 & 0.9 \\
$\mathrm{Control}$ & 0.20 & 3 & 11.3 & 0.3 \\
\hline
\end{tabular}




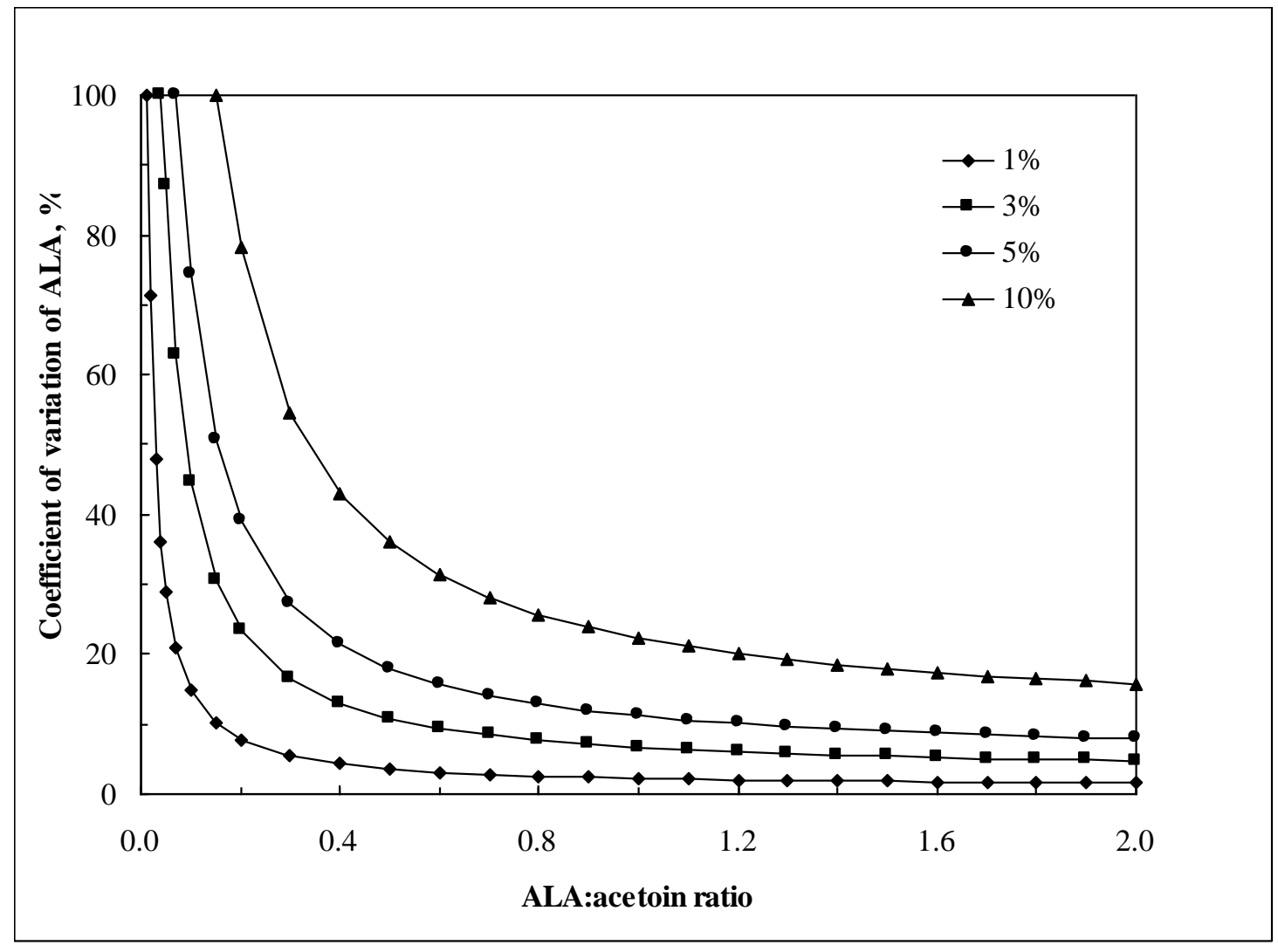

2

5 Figure 1. Modelling the effect of the ratio of 2-acetolactate to acetoin on the

6 coefficient of variation of 2-acetolactate as determined by the Westerfeld (1945)

7 procedure. The CVs of acetoin used are shown in the legend. 


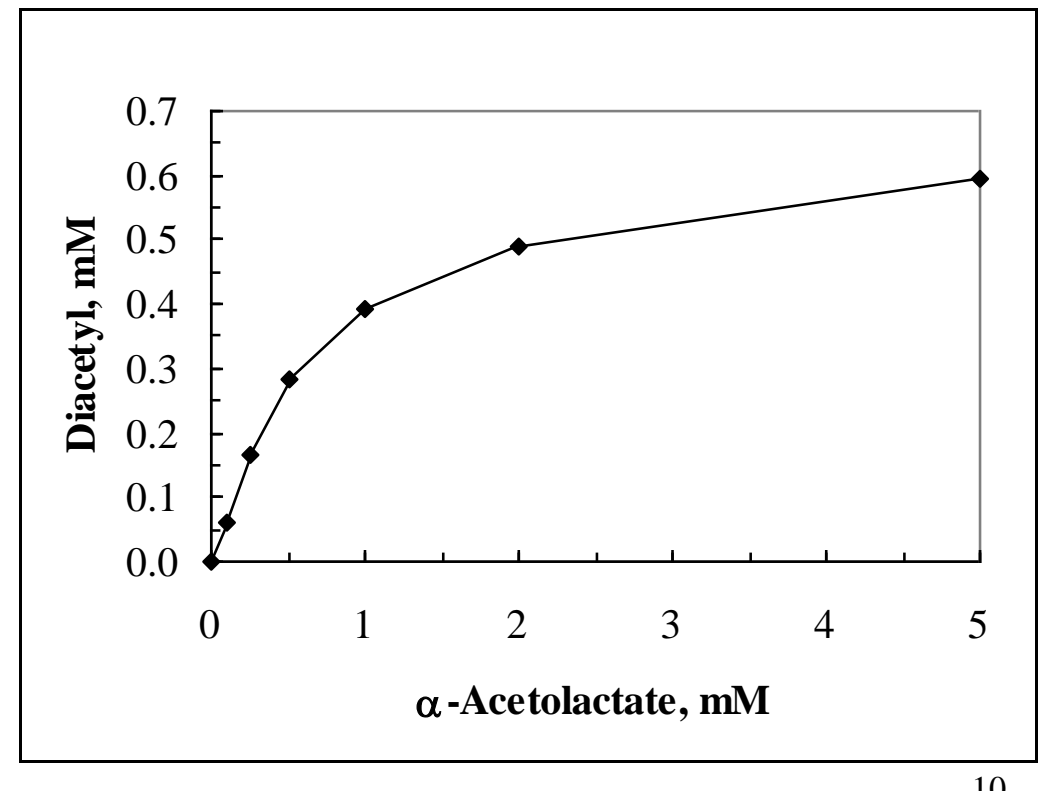

11

12 Figure 2. Production of diacetyl from 2-acetolactate during steam distillation of milk at pH 4.0 using the method of Gollop et al (1987).

14 


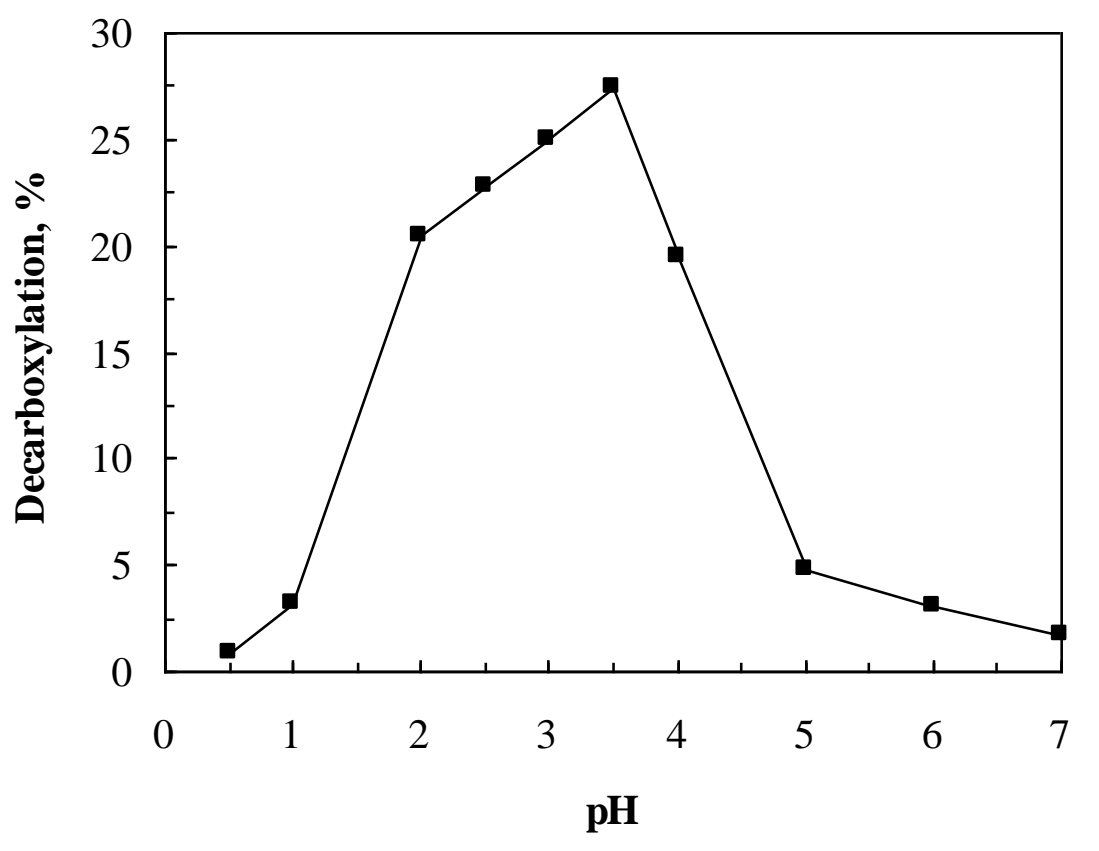

5

6

7 Figure 3. Effect of $\mathrm{pH}$ on the production of diacetyl from 2-acetolactate in milk during 8 steam distillation. The initial level of 2 -acetolactate was $1 \mathrm{mM}$. 


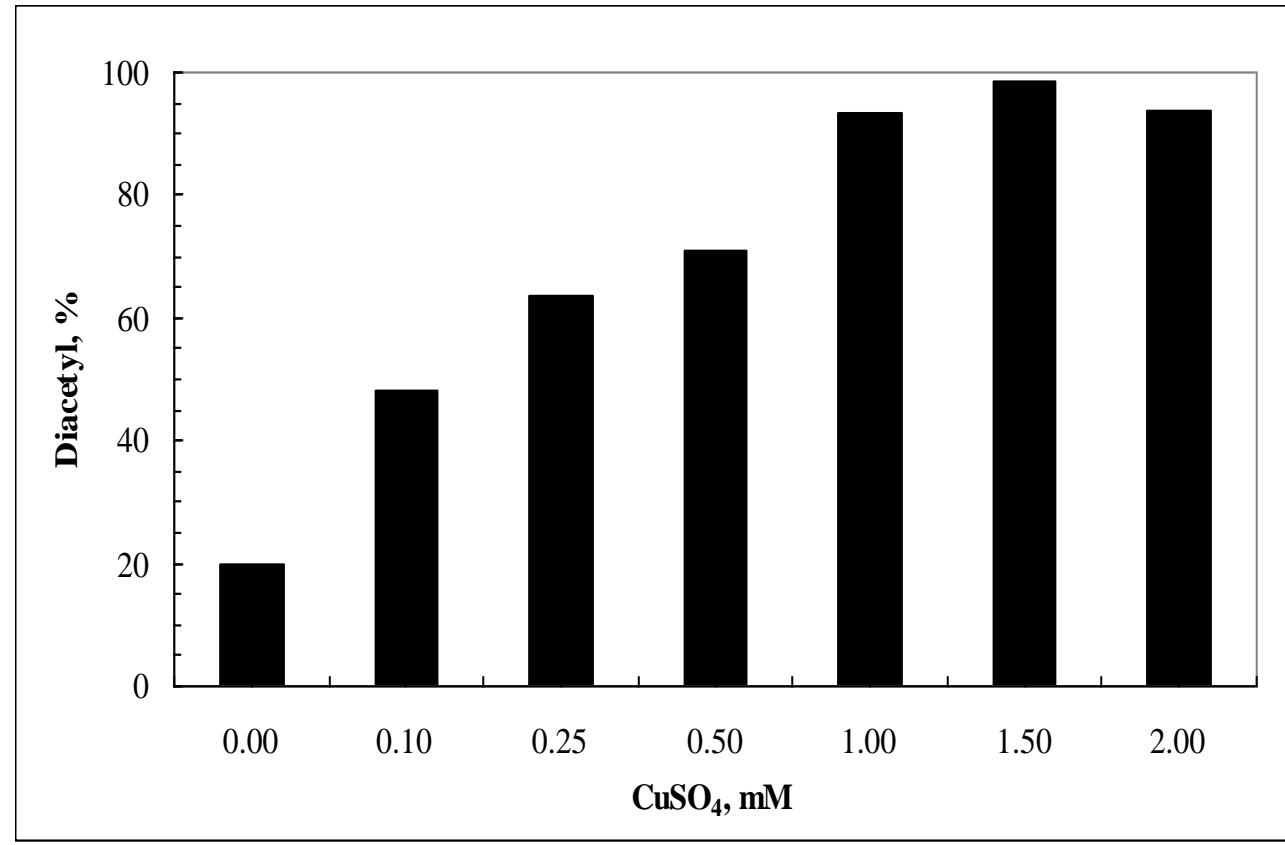

2

3

4 Figure 4. Effect of $\mathrm{CuSO}_{4}$ on the decarboxylation of 2-acetolactate to diacetyl in milk

5 during steam distillation at $\mathrm{pH}$ 3.5. The initial concentration of ALA was $1 \mathrm{mM}$. 


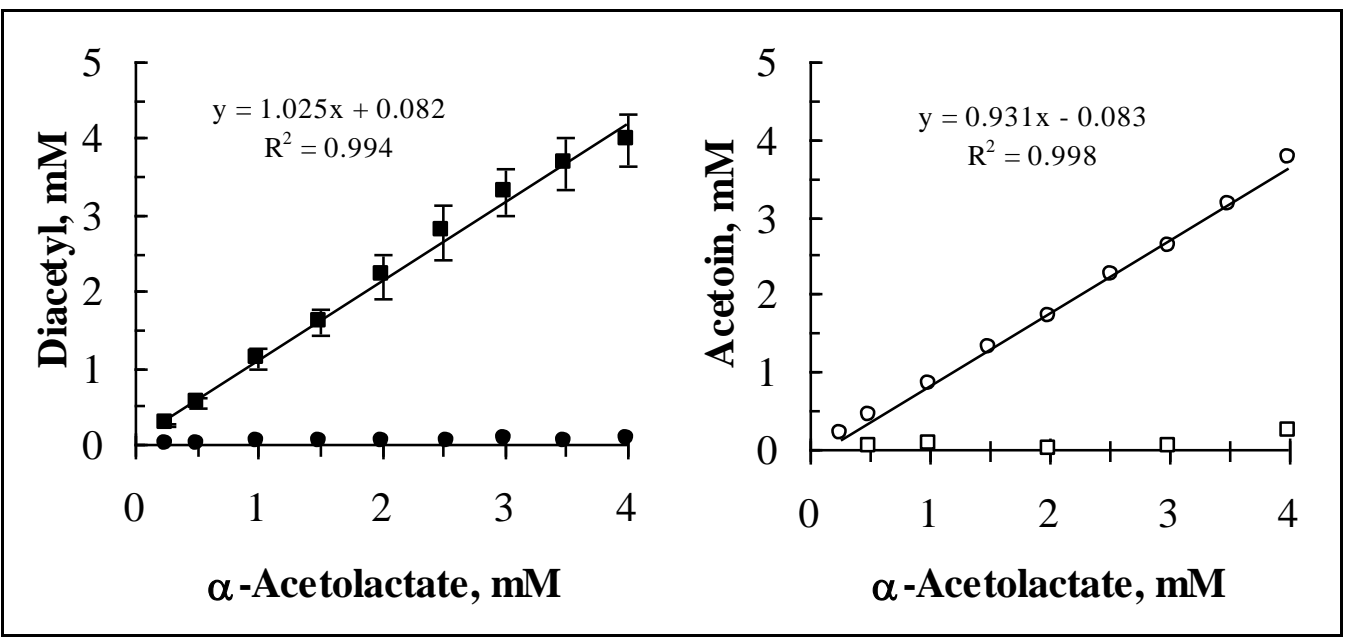

2

5 Figure 5. Decarboxylation of 2-acetolactate to diacetyl (closed symbols) and acetoin

6 (open symbols) at $\mathrm{pH} 3.5$ in the presence of $\mathrm{CuSO}_{4}$ (squares) and at $\mathrm{pH} 0.5$ in the

7 absence of $\mathrm{CuSO}_{4}$ (circles). The regression equations for diacetyl production at $\mathrm{pH} 3.5$

8 and acetoin production at $\mathrm{pH} 0.5$ are shown. For clarity, the trend lines for diacetyl

9 production at $\mathrm{pH} 0.5$ and acetoin production at $\mathrm{pH} 3.5$ are omitted. 


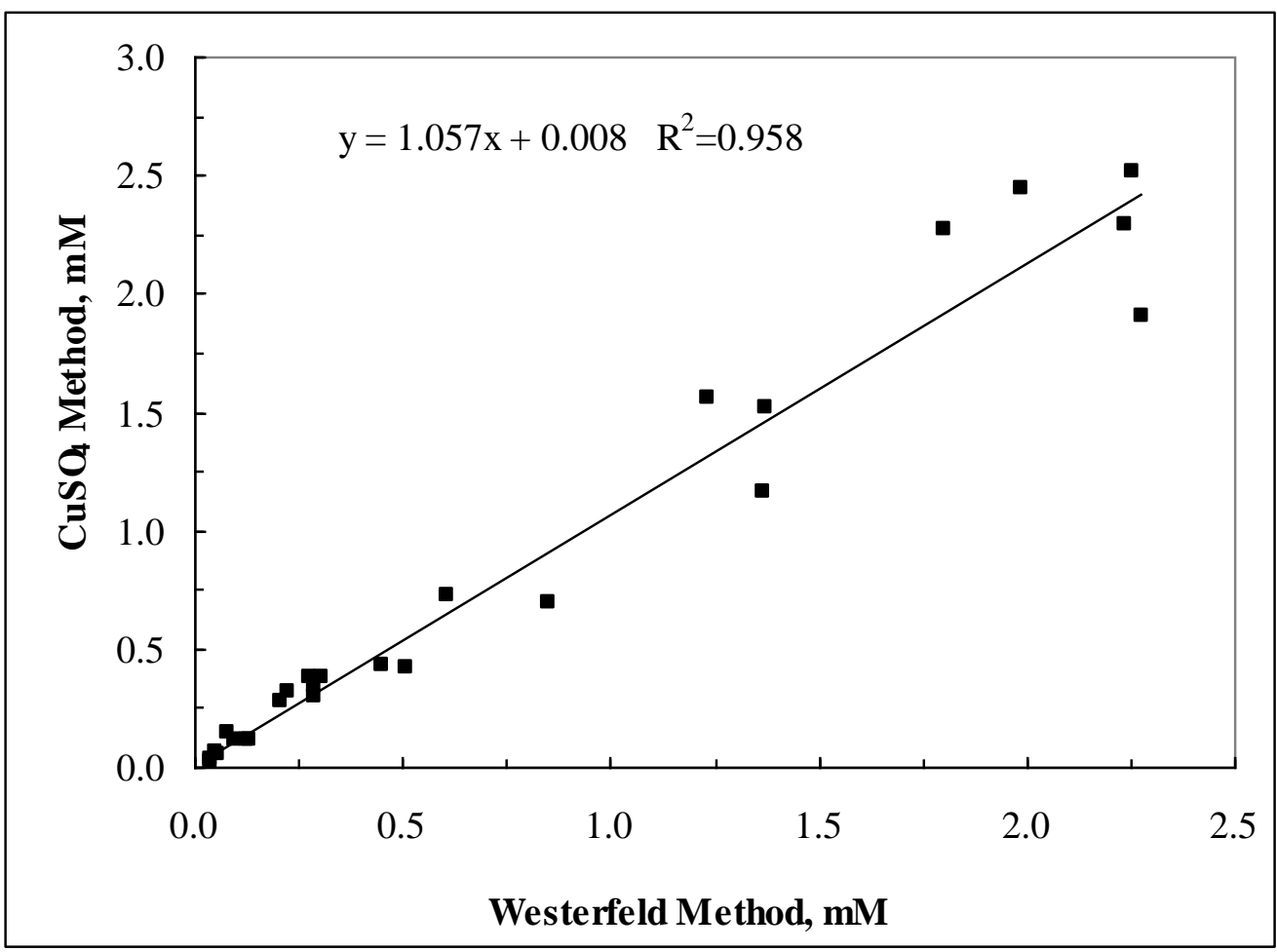

2

6 Figure 6. Regression of the $\mathrm{CuSO}_{4}$ method for measuring 2-acetetolactate on the

$7 \quad$ Westerfeld method. The regression equation is shown. 


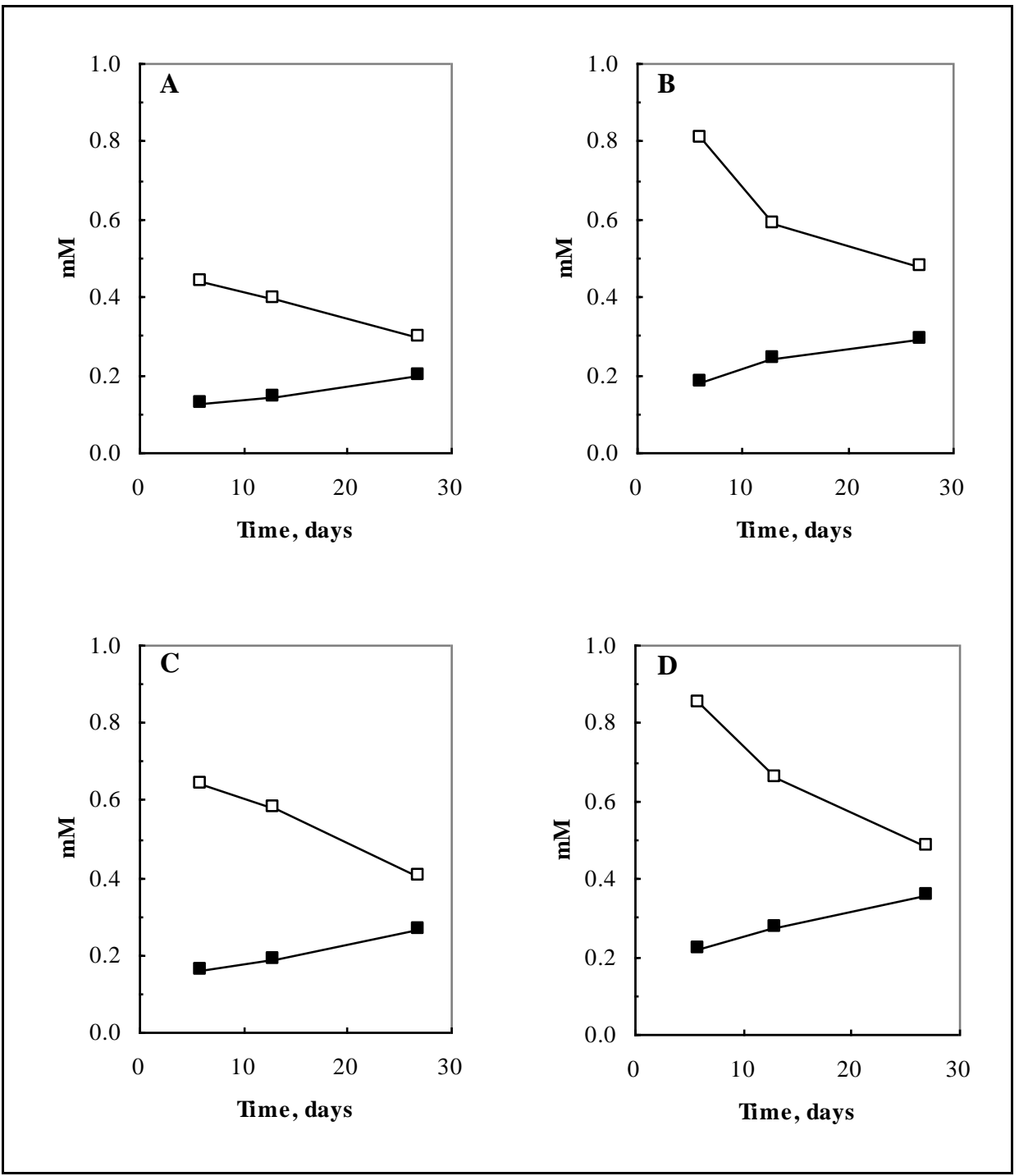

2

3

4 Figure 7. Changes in the concentrations of diacetyl (closed symbols) and 2-

5 acetolactate (open symbols) in 4 samples of quarg during storage at $4^{\circ} \mathrm{C}$.

6 